Geosystems of Transition Zones, 2020, vol. 4, N 1, p. 26-34

Геосистемы переходных зон, 2020, т. 4, № 1, с. 26-34

https://doi.org/10.30730/2541-8912.2020.4.1.026-034

\title{
Are tsunamis long or dispersive waves?
}

Yury P. Korolev*
Pavel Yu. Korolev

\author{
Institute of Marine Geology and Geophysics, FEB RAS, \\ Yuzhno-Sakhalinsk, Russia
}

*E-mail:Yu_P_K@mail.ru

\section{Abstract Резюме Rus PDF}

Long and dispersive waves are transformed differently when propagating in the ocean. Dispersive waves are characterized by faster attenuation than long waves. The change in the amplitude and period of the head wave depending on the run time was studied. The boundaries to which a tsunami can be considered as a long wave were estimated. The criterions of whether a tsunami belongs to dispersive or non-dispersive (long) waves were the degree of attenuation of the amplitude and the degree of increase in the duration of the head wave period, depending on the run time. The actual moments of time when the dispersion begins to manifest were compared with different theoretical estimations of the dispersion length (time). The depth of the ocean in the focus has a significant influence on the tsunami nature: with the same earthquake magnitude, tsunamis that occur in foci with a lower depth of the ocean are less susceptible to dispersion. Estimates of the dispersion times and, consequently, knowledge of the nature of the waves are necessary for the adequate application of certain models for calculation. In some cases, it seems sufficient to use simpler equations of long shallow-water waves to calculate tsunamis; in others, it is necessary to use complete nonlinear-dispersion equations.

\section{Keywords}

tsunami, magnitude of earthquake, long waves, dispersive waves, dispersion length, dispersion time

For citation: Korolev Yu.P., Korolev P.Yu. Are tsunamis long or dispersive waves? Geosystems of Transition Zones, 2020, vol. 4, no. 1, p. 26-34. (In Russian). https://doi.org/10.30730/25418912.2020.4.1.026-034

Для цитирования: Королев Ю.П., Королев П.Ю. Волны цунами: длинные или диспергирующие? Геосистемы переходных зон. 2020. Т. 4, № 1. С. 26-34. https://doi.org/10.30730/25418912.2020.4.1.026-034

\section{References}

1. Bolshakova A.V., Nosov M.A. 2011. Parameters of tsunami source versus earthquake magnitude. Pure Appl. Geophys, 168: 2023-2031. doi:10.1007/s00024-011-0285-3

2. Fedotova Z.I., Khakimzianov G.S. 2010. [Nonlinear-dispersive shallow water equations on the rotating sphere]. Vychislitel'nye tekhnologii [Computing technologies], 15(3): 135-145. (In Russ.).

3. Gazarian Iu.L. 1955. [About the ocean surface waves, excited by the undersea earthquakes]. Akusticheskij zhurnal = Acoustical Physics, 1(3): 203-217. (In Russ.).

4. Glimsdal S., Pedersen G.K., Harbitz C.B., Lovholt F. 2013. Dispersion of tsunamis: does it really matter? Natural Hazards and Earth System Sciences, 13: 1507-1526. doi:10.5194/nhess-13-1507-2013

5. Gusev O., Beisel S. 2016. Tsunami dispersion sensitivity to seismic source parameters. Science of Tsunami Hazards, 35(2): 84-105.

6. Handbook for tsunami forecast in the Japan Sea. 2001. Earthquake and Tsunami Observation Division, Seismological and Volcanological Department, Japan Meteorological Agency, 22 p. 
7. Korolev P.Yu., Korolev Yu.P., Loskutov A.V. 2019. Analysis of the main characteristics of tsunamis based on data from deep-ocean stations. IOP Conf. Series: Earth and Environmental Science, 324(012017). doi:10.1088/1755-1315/324/1/012017.

8. Mirchina N.P., Pelinovsky E.N. 1981. The dependence of tsunami wave period on the source dimensions. Marine Geodesy, 5(3): 201-208.

9. Mirchina N.P., Pelinovsky E.N. 1982. Nonlinear and dispersive effects for tsunami waves in the open ocean. Int. J. Tsunami Society (Natural Science of Hazards), 2(4): D1-D9.

10. Mirchina N.P., Pelinovsky E.N., Shavratsky S.Kh. 1982. Parameters of tsunami waves in the source. Int. J. Tsunami Society (Natural Science of Hazards), 2(4): B1-B7.

11. National Centers for Environmental Information. URL: https://www.ngdc.noaa.gov/nndc/struts/form?t=101650\&s=70\&d=7 (access: 25.01.2020).

12. National Data Buoy Center. URL: https://ndbc.noaa.gov/dart.shtml (access: 17.12.2019).

13. NOAA Center for Tsunami Research. URL: http://nctr.pmel.noaa.gov/Dart (access: 17.12.2019).

14. Vladimirov V.S. 1976. [Equations of mathematical physics]. Moscow: Nauka, 528 p. (In Russ.). 